Jurnal Kejuruteraan SI 1(4) 2018: 65-73

http://dx.doi.org/10.17576/jkukm-2018-si1(4)-09

\title{
$i$-Methodology Development for Compositional Analysis of Lignocellulosic Biomass Using Visual Basic Application
}

\author{
Nor Shahirah Ishak ${ }^{\mathrm{a}}$ * Shuhaida Harun ${ }^{\mathrm{a}, \mathrm{b}}$ \\ ${ }^{a}$ Chemical Engineering Programme \\ ${ }^{b}$ Research Centre for Sustainable Process Technology (CESPRO), \\ Faculty of Engineering \& Built Environment, Universiti Kebangsaan Malaysia
}

ABSTRACT

Chemical composition of lignocellulosic biomass $(L C B)$ is an important parameter to be determined in order to identify the chemical potential in LCB. The compositional analysis of $L C B$ is the first analysis performed prior to any LCB conversion process to produce high value-added products. LCB composition is generally characterized according to Laboratory Analytical Procedures (LAPS) published by National Renewable Energy Laboratory (NREL), USA. Major chemical components determined are glucan, xylan, arabinan, galactan, mannan, ash, extractives and lignin. The mathematical parts performed manually in the compositional analysis are tedious, complex and repetitive due to the interrelation of calculations within each chemical component. These manual calculations for each chemical component should be performed carefully and systematically to avoid errors in the final results of LCB composition. Therefore, this research work developed a computerized method to perform automatic LCB composition calculation system using Visual Basic (VB) software integrating its Graphical User Interface (GUI) concept to help users in performing the LCB composition calculation specifically for biomass-based research use.

Keywords : Lignocellulosic biomass; compositional analysis; graphical user interface

ABSTRAK

Komposisi kimia biojisim berlignoselulosa adalah parameter penting untuk ditentukan bagi mengenal pasti potensi komposisi kimia yang terkandung dalam LCB. Penentuan komposisi merupakan analisis pertama yang dilakukan sebelum proses penukaran LCB untuk menghasilkan produk tambah nilai tinggi. Komposisi LCB amnya dicirikan mengikut Tatacara Analysis Makmal (LAPS) terbitan National Renewable Laboratory (NREL), USA. Komponen kimia utama yang ditentukan adalah glukan, xilan, arabinan, galaktan, mannan, abu, ekstraktif dan lignin. Bahagian pengiraan matematik analisis komposisi yang dibuat secara manual adalah rumit, kompleks dan berulang-ulang kerana pengiraan komponen kimia yang berkait di antara satu sama lain. Pengiraan komposisi secara manual untuk setiap komponen kimia perlu dilakukan dengan teliti dan bersistematik untuk mengelak ralat dalam komposisi akhir LCB. Oleh itu, kajian penyelidikan telah dijalankan untuk membangunkan satu kaedah berkomputer untuk melakukan pengiraan komposisi LCB berautomatik menggunakan perisian Visual Basic (VB) menyepadukan konsep Antara Muka Pengguna Grafik (GUI) untuk membantu pengguna dalam pengiraan komposisi LCB khususnya untuk penggunaan dalam penyelidikan biojisim.

Kata kunci: Biojisim berlignoselulosik; analisis komposisi; antara muka pengguna grafik

\section{INTRODUCTION}

Dependency on non-renewable source leads current research on the alternative sources of energy in order to replace current deficiency on energy sources. Lignocellulosic biomass (LCB) is one of the sources capable to become the alternative energy source particularly in the production of bioenergy (Deutschmann \& Dekker 2012). Data on LCB composition is very important to be analyzed in order to determine the potential and utilization of the chemical components in LCB. The biomass conversion into high value-added product yield depends significantly with biomass composition. Accurate quantification of chemical composition of LCB enables conversion process, product yield and economic evaluation to be identified.
LCB is living materials which can be divided into several types such as plant crops, industrial residue and forest waste. LCB is one of the most common types of biomass used widely in biorefinery process. Selection of biomass usually depends on the availability of abandoned biomass on certain location within the country. According to Sluiter et al. (2010), the main compositions of LCB are cellulose, hemicellulose and lignin. Hames 2009 describes that cellulose, hemicellulose, lignin and protein build up structural component of LCB where ash and extractives are non-structural components. The composition variation depends on types of LCB and cell tissue location in the plant crops (Sluiter et al. 2013).

There are several establish methods to quantify composition of LCB such as Laboratory Analytical Procedures (LAPs) published by National Renewable Energy Laboratory 
(NREL) and procedures from Technical Association of Pulp and Paper Industry (TAPPI). In this study, computation of LCB composition is based on LAPS from NREL. TAPPI procedures are more suitable for pulp and paper industries whilst NREL is mostly used by other researchers for LCB conversion to energy application. According to Sluiter 2010, combination of LAPs allows for summative mass closure of LCB and process intermediates. Long and complex calculations for LCB composition quantification requires calculations of chemical components as stated in LAPs. Appropriate combination of LAPs enable proper composition quantification to avoid errors during summative mass closure (Hames 2009). Summative mass closure is goal to break the LCB down into components such as glucan, xylan, mannan, arabinan, galactan, acid soluble lignin, acid insoluble lignin, protein, ash and extractives which eventually sum to hundred percent by weight.

Visual Basic (VB) is a programming language and integrated development environment from Microsoft as its Component Object Model (COM) programming model. VB have user-friendly programming language which enables graphical user interface (GUI) application. VB is widely used for computation and simulation for industrial and research purpose. Complex system development may require high functioning software such as (Singh \& Fen 2011) using Microsoft Visual C\# in designing smart drawer system for document tracking purpose. For computation of LCB composition in this study, VB was found suitable to develop a calculation system using GUI concept. There is no other study or software developed for this compositional analysis purpose. Since for composition analysis requires long and complex calculation, this computer aided system allows researcher as users use lesser time to calculate LCB composition with accurate result. Therefore systematic system with GUI concept is developed in this study to assists the calculation for LCB compositional analysis used specifically for research activity.

\section{METHODOLOGY}

In order to develop system for compositional analysis of LCB, there are several steps considered such as manual calculation method, development of software architecture, development of module and errors determination. Referring to NREL, the procedural and sequence of biomass compositional analysis is strictly followed the LAPS. The formulas of each calculation for all chemical compositions are also based on NREL LAPS.

Figure 1 shows flowchart of research methodology conducted in the study. In order to develop software for biomass composition analysis, raw data must first be obtained from previous study so that it can be used as input for software development. This raw data was then used to calculate the composition of biomass manually before it tested with the developed system. Both manual and developed system calculation for compositional analysis were carried out in order to determine errors with these two methods.

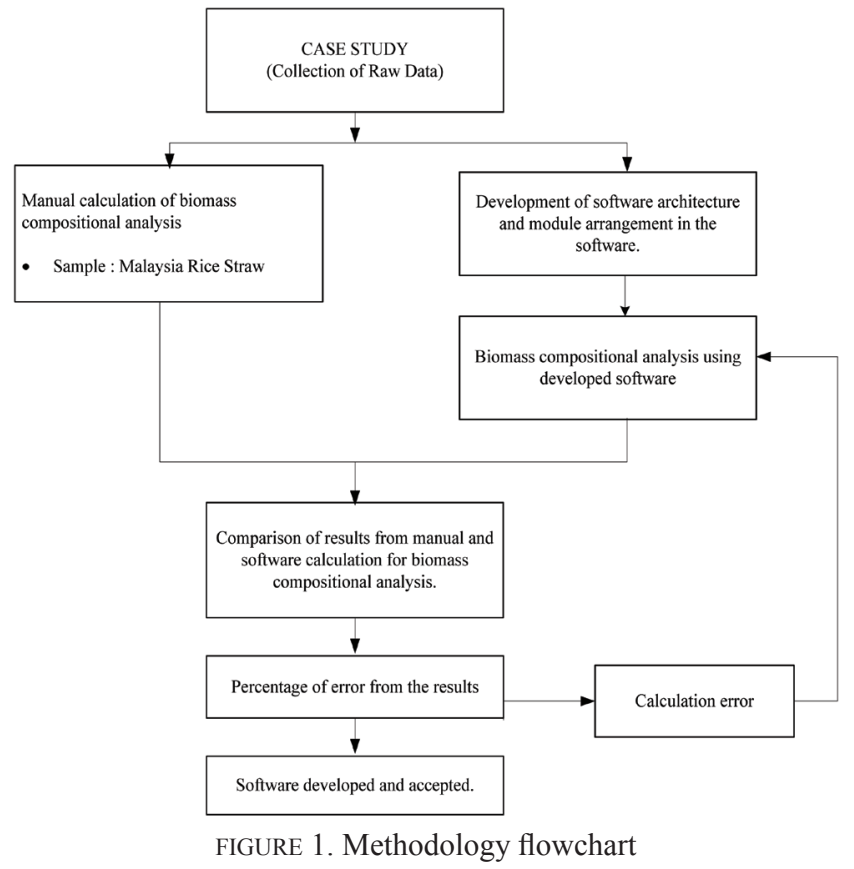

MANUAL CALCULATION

Manual calculation is carried out by plug in the raw data into the formula as stated in NREL LAPs. This raw data was obtained from previous study of biomass compositional analysis wet laboratory experiments. The samples of biomass were from Malaysia Rice Straw. The composition were manually calculated using typical excel sheet and referring strictly to LAPs to get the composition of LCB.

\section{MODULE DEVELOPMENT}

Module for each analysis was developed by programming the calculation for all the component analysis. This programming includes the formula related to that specific calculation. Module involved are, moisture content analysis, ash analysis, extractive analysis, protein analysis and carbohydrate and lignin analysis. This analysis is related to each other, thus correct sequencing of the programming is needed so that acceptable result is obtained.

Calculation of total solid and oven dry weight (ODW) are required as this information is needed to perform calculation in other modules. The formula to calculate total solid and ODW is shown as in Equation 1 and Equation 2 below:

$$
\begin{aligned}
& \% \text { Total Solid }=\frac{\text { Weight }_{\text {dry pan }+ \text { drysolids }}-\text { Weight }_{\text {dry pan }}}{\text { Weight }_{\text {sampleas received }}} \times 100 \\
& O D W_{\text {sample }}=\frac{\text { Weight }_{\text {air dried sample }} \text { Weight }}{100}
\end{aligned}
$$

Inorganic materials that present in biomass sample give significant contribution to total mass closure, thus it is necessary to calculate the composition of inorganic materials in form of ash. The formula to calculate percentage of ash in biomass samples are as in Equation 3. 


$$
\% A s h=\frac{\text { Weight }_{\text {cruible plus ash }}-\text { Weight }_{\text {cruible }}}{O D W_{\text {sample }}} \times 100
$$

The formula for calculate percentage of extractives content for both water and ethanol is as in Equation 4.

$$
\% \text { Extractives }=\frac{\text { Weight }_{\text {flask plus extractives }}-\text { Weight }_{\text {flask }}}{O D W_{\text {sample }}} \times 100
$$

The calculations for percentage of acid-soluble lignin in the development of lignin module are as in Equation 5

$$
\% A I L=\frac{\left(\text { Weight }_{\text {acid insoluble lignin }}\right)}{\text { weight of samble on unextracted basis }} \times 100
$$

Where AIL is asid-soluble lignin. And finally to develop carbohydrates, the formula used is as shown in Equation 6.

$$
\% \text { Sugar }=\frac{\text { concentration }_{\text {sugar }} \times \text { volume }_{\text {filtrate }}}{O D W_{\text {sample }}} \times 100
$$

Thus, from the above equations, modules are developed by expanding the equations and suit with other relevant equations to produce software that able to perform compositional analysis calculations.

VB allows codes to be created using module, class module and userform. Calculation of each chemical to another component, coding on userform were created accordingly. The example for some codings on userform was shown as in Figure 2.

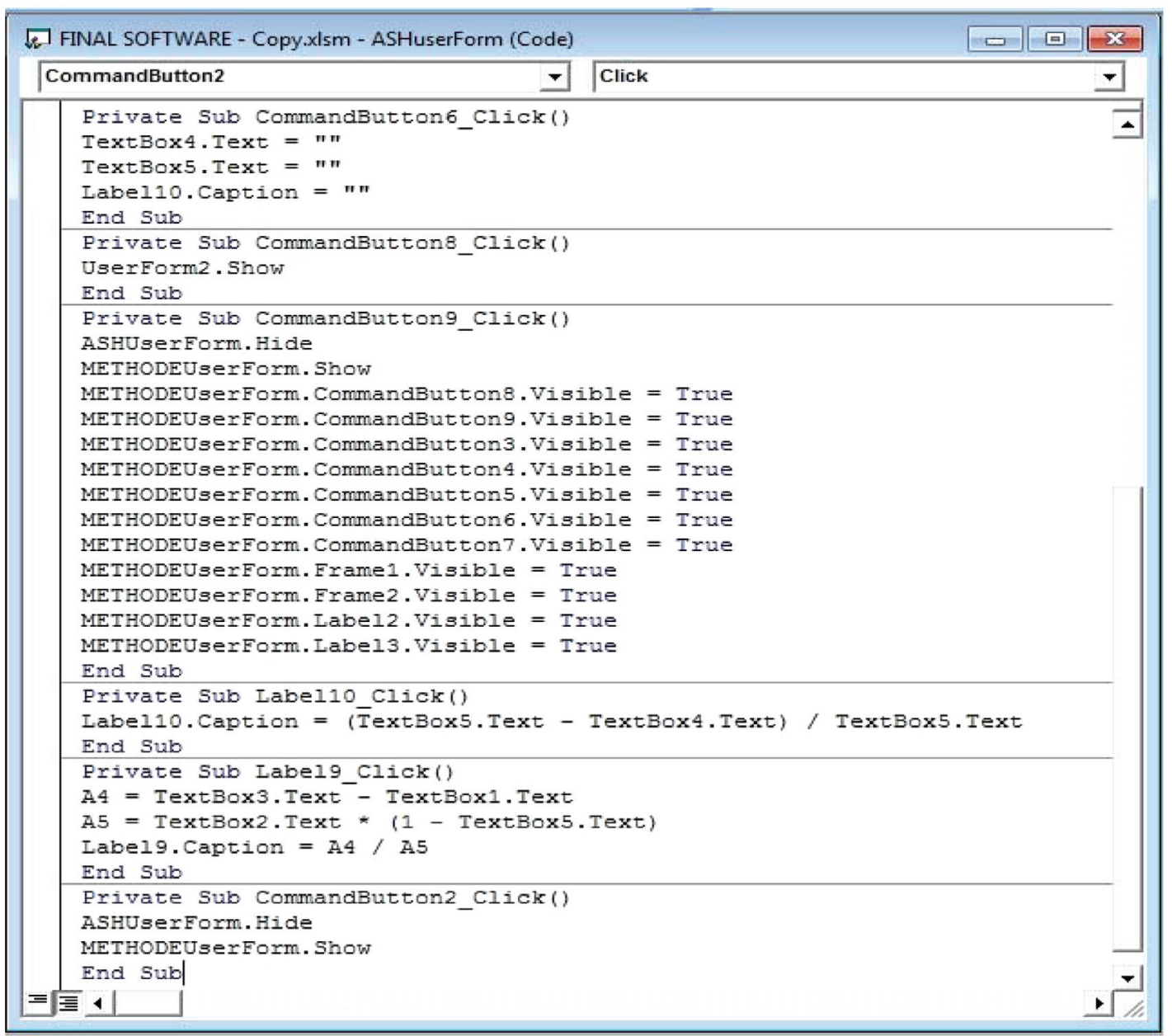

FIGURE 2. Examples of VB Coding

\section{VISUAL BASIC APPLICATION}

Microsoft Visual Basic 6.5 in Microsoft Excel 2007 was used to wrote all the coding in order to develop this software.

\section{ERRORS}

Errors are calculated after the result for both manual and system obtained. Calculation error is determined by summation of the result for compositional analysis Supposedly the total composition of the components are approaching $100 \%$, however calculation error will lead to deviation of the results. The equation related to error calculation is as in Equation 7

$$
\text { Error }=\frac{\text { value manual calculation }- \text { value in system }}{\text { value in manual calculation }} \times 100
$$




\section{RESULTS AND DISCUSSION}

The developed software was first designed by arranging the modules in the system. The developed software architecture is shown in Figure 3. The arrangement of the modules is based on NREL protocols. Software architecture was designed to give overall picture on how the system works from the beginning until the end. Thus the flows of the system from one page to another strictly follow the software architecture. The system starts with "welcome page" where users are required to logging in their username and password as shown in Figure 4. As the logged in successful, main menu page display will appear as shown in Figure 5. This page will allow users to choose either to proceed with compositional analysis using NREL or TAPPI method. Since NREL and TAPPI are well established method for compositional analysis, therefore these two methods were initially planned to include in this system. But however, only NREL method is accessible at the moment while TAPPI method will be added on later version. After users choose NREL method, "Selection of analysis" display will appear as shown on Figure. NREL compositional analysis method consists of several components analysis as mention before where it includes carbohydrate, lignin, ash, extractives, and protein analysis. For research purpose, some biomass does not require certain analysis such as protein. Thus this system allows users to choose whether to proceed with single component analysis or to proceed with overall analysis. Overall analysis according to NREL follow sequentially starts with ash analysis, followed by extractive, carbohydrate, lignin and protein analysis.

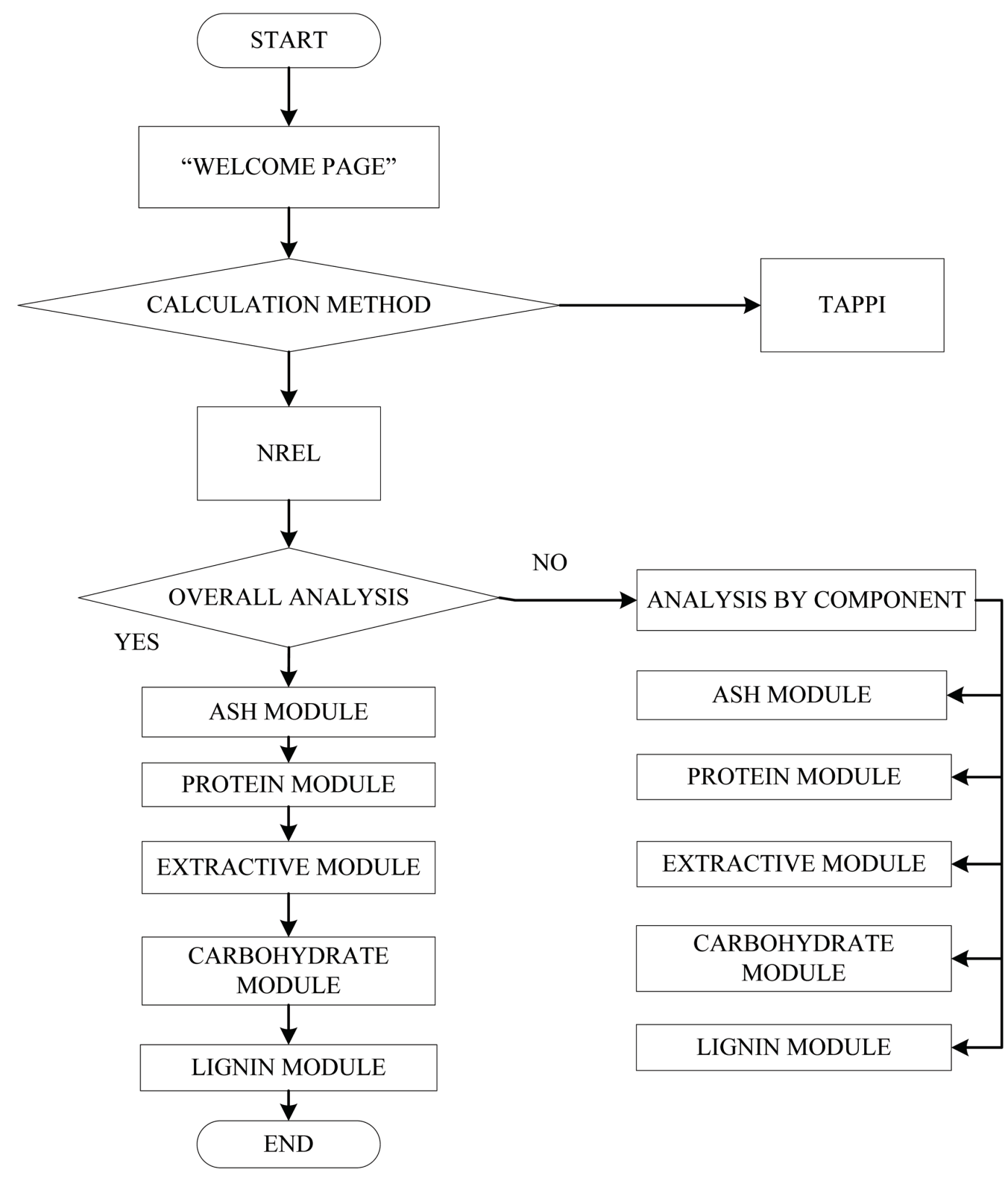

FIGURE 3. Software architecture 
ASH MODULE

Ash module was developed to quantitatively quantify amount of ash in the sample on percent dry weight biomass basis. This analysis requires user to give information on weight of biomass before and after LCB burning using furnace at $575^{\circ} \mathrm{C}$. Moisture content of LCB also needed in order to quantify ash. For past case studies moisture content information was obtained from moisture analyzer, therefore the calculation of moisture content was not used. The moisture content information obtained from raw data of 11.2 was included directly in the system to continue calculations for ash analysis as shown in Figure 4.

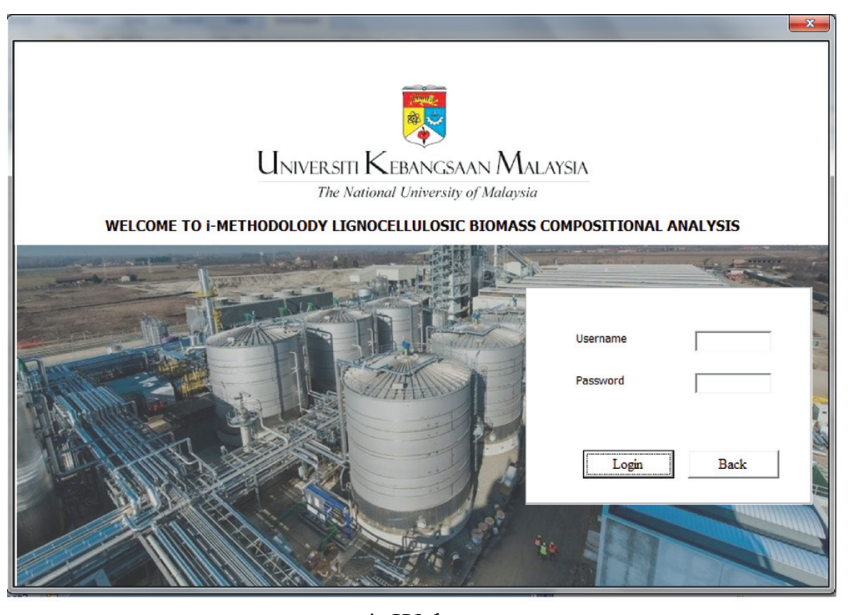

FIGURE 4. Welcome page

The raw data information to be included for ash analysis such as the weight of the empty crucibles, the biomass wet weight with crucible and the weight of the crucibles with ashes. The values for this information were filled in the module, and the calculation shows the percentage of ash content contained in this LCB sample is 16.03 percent. The calculated value of using system is the same as the value obtained from manual calculation

\section{EXTRACTIVES MODULE}

The extractive module is a computational analysis module for extractable components in LCB samples. The module for this extractive analysis is divided into three parts, namely the total extraction calculations, water extraction calculations and ethanol extraction calculations. The extraction process introduced by NREL to extract unstructured components in biomass samples is by using water and ethanol as solvent (Sluiter et al. 2008). Materials from biomass samples dissolved in water during the water extraction process include inorganic materials, non-structural sugar, and nitrogenous substances. Whereas, dissolved substances in ethanol solvents are chlorophyll, wax materials, and other minor components (Hames et al. 2008). For calculations in this extractive module, user will be accessed to the full extractive display of the extraction, then display the extractive computational view and finally to the extraction calculations of ethanol.
Extractive extraction view is as shown in Figure 5. For this calculation, users need to filled inputs such as the weight of the fiber filter, the wet weight of the biomass along with the extracted cells, and the dry weight of the biomass extracted with the filter. Inputs for moisture content should also be included such as moisture content of wet weight and dry weight moisture content of the biomass sample. The calculation results from the inputs entered by user will be processed by the system to provide the entire extractive information result and total extractive percentage. In the calculation using this system, the overall extraction percentage obtained was 13.75 percent.

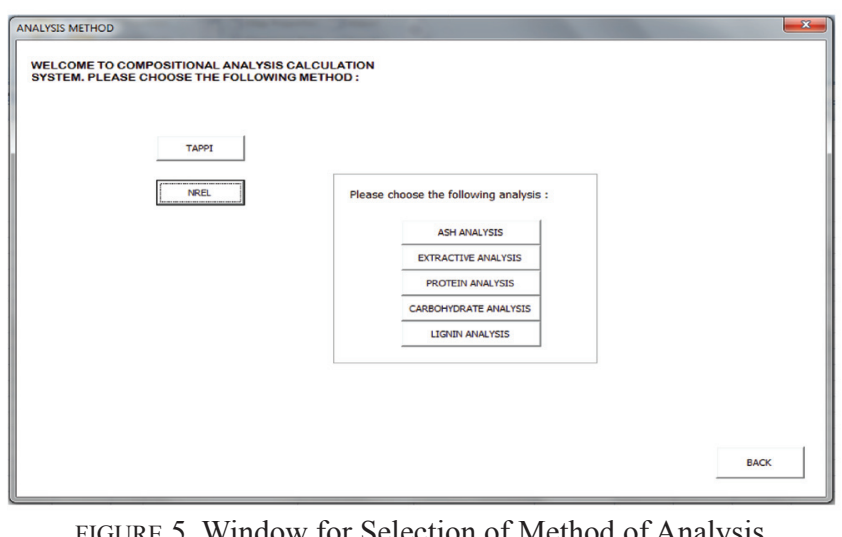

The importance of obtaining the whole extractive information is to give the overall value of the extracted component from the LCB sample. This is due to extractive composition is composed of various components, there are components that can be characterized and some are not (Hames 2009). Among the components characterized include dissolved sugars such as acetyl, glucose, sucrose and fructose (Hames 2009). The soluble sugar values in this extraction will then be re-added into the calculated sugar composition calculated on the carbohydrate module for the purpose of correction of the value at the end of the overall analysis.

Additionally, it should be emphasized that the extraction process needs to be done before the carbohydrate analysis process. This is because the failure to isolate the nonstructured material from the biomass sample during the process of carbohydrate and lignin analysis has resulted in it being misplaced as lignin. This is because some of the components in the extraction are insoluble in acid during the process of hydrolysis in the carbohydrate and lignin analysis.

Thus, this compound will be precipitated and will be considered as lignin. If this happens, the lignin composition will increase and make the total value of the overall composition of the components in the biomass sample are not accurate.

For water extraction calculations, the main purpose of this calculation is to obtain the percentage of dissolved sugar and oligomeric sugar during the extraction process using water. During the analysis laboratory, the user should obtain a sharp data from water extraction analysis using High Performing 
Liquid Chromatography (HPLC). The data obtained from this HPLC should be included in this software system to obtain the percentage of soluble sugar and oligomeric sugar found in the original biomass sample. The extraction for this extraction calculation is shown in Figure 5.

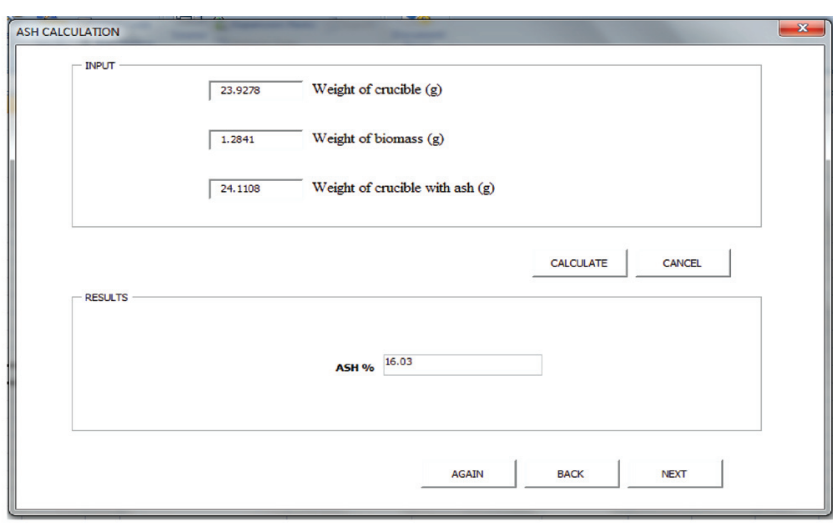

FIGURE 6. Ash Module

For extraction of ethanol, calculations were made to extract the extraction percentages of ethanol from the entire LCB sample. The content in the ethanol extract are not characterized. In ethanol extract, there are various minor compositions such as chlorophyll and wax materials. Thus, the extraction from the extraction analysis of ethanol is incorporated as an extraction of ethanol only though there are other minor components found in it.

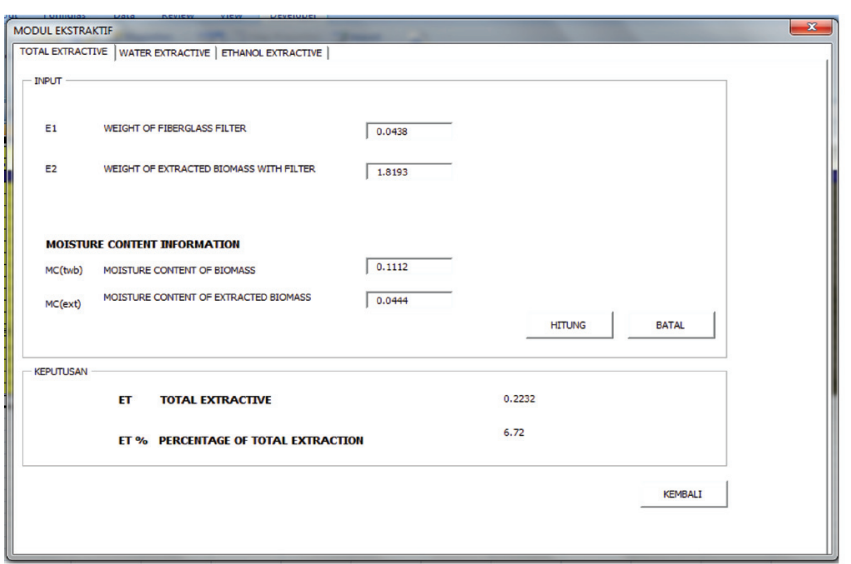

FIGURE 7. Extractive Module

CARBOHYDRATE MODULE

Calculation of carbohydrate analysis is one of the complex calculations compared to other components. For the calculation of structured carbohydrate composition, the user will be accessed to the display of carbohydrate analysis as shown in Figure. The inputs that need to be included are the volume of hydrolysate, dry weight of LCB added, and the sugar concentration readings obtained after the analysis using HPLC. This data should be taken during the wet lab done after the hydrolysis process. In order to obtain glucan, xylan, arabinan, and acetyl content, these data are calculated with addition of values from structural sugars obtained in the water extract.

According to raw data processed by the system, percentage of total structured carbohydrates such as glucan, xilan, arabinan and acetyl are 35.90, 21.60, 4.59, and 1.79 respectively. The calculation results using this system are slightly different from manual calculations. This is because the calculations for this structured carbohydrate analysis are long and interconnected with other components of LCB. Hence, for every calculations made by the system, the number of decimal place are taken into account and gives different decimal values compared to manual calculations. However, the difference between these values is not significant and the results obtained still can be applied.

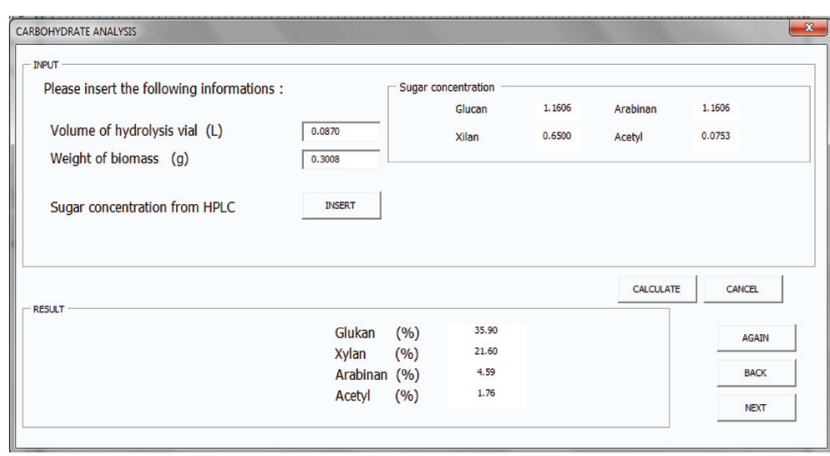

FIGURE 8. Carbohydrate Module

LIGNIN MODULE

Lignin is a complex phenolic polymer and is one of the major compositions of LCB apart from cellulose and hemicellulose. The lignin content can only be analyzed after the hydrolysis process is performed. Lignin is divided into acid-soluble lignin and acid-insoluble lignin. For analysis of lignin in this system, only values of acid-insoluble lignin are quantified and displayed. The display for lignin analysis is shown in Figure 7.

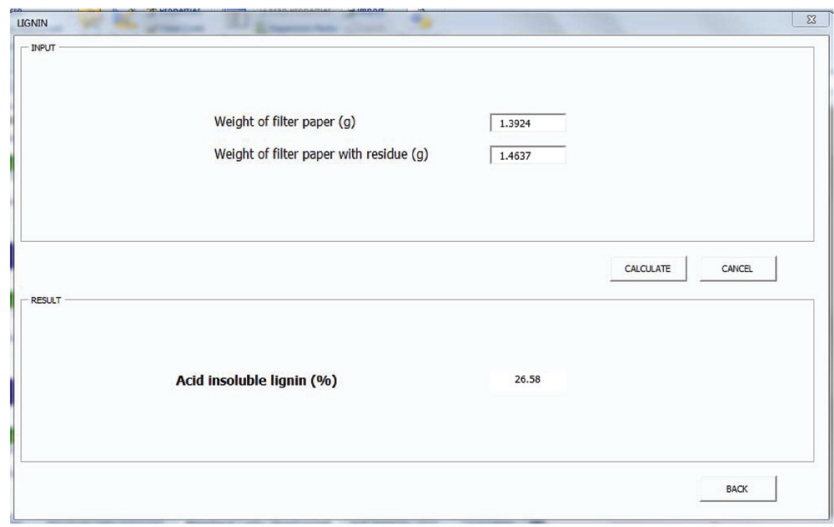

FIGURE 9. Acid-Insoluble Lignin Module 
Acid-insoluble lignin is an insoluble lignin in the acid during the hydrolysis process. Thus, in order to obtain acidinsoluble lignin content, the filtration process is performed on the acid solution after the hydrolysis acid process. The insidious residues in these acids are considered as nonacid soluble lignin. Therefore, the residual weight after the filtration process is to be taken and included as input in this system. This system will process the inputs and provide percent of lignin-non-soluble acid content.

The information users need to put into the system is the weight of the filter paper and plates before and after the filtration process. Weight for after filtration process contains insoluble lignin content. In this case, the weight before the filtration process is 1.3924 gram while for after the filtration process is 1.4637 gram. Analysis using this information provided a percentage of acid-insoluble lignin content of 26.58 percent.

\section{PROTEIN MODULE}

The protein analysis module is a module that allows analysis of protein content calculation in the LCB sample. The raw data required in this protein module involves the reading of the Nitrogen Analyzer instrument. Protein reading of this protein must be performed before and after the extraction process to obtain protein content before the extraction process and the protein is extracted during the extraction process. Both of these values need to be taken into account for correction of values at the end of the analysis and avoid double counting of the protein components in LCB samples. The display for the calculation of the protein content is shown in Figure 8.

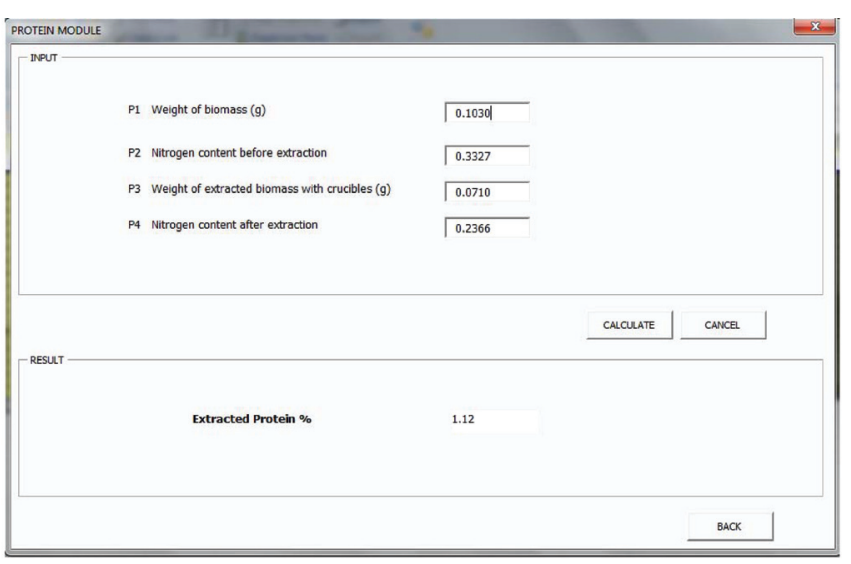

FIGURE 10. Protein Module

From the computational analysis of this protein, user will get information such as extracted protein content. From raw data information included in systems such as biomass weight, nitrogen content before extraction, extracted biomass weight, and nitrogen content after extraction, extracted extraction results obtained was 1.12 percent. This value is equal to the value obtained from manually calculated calculations. Thus, this protein module provides precise calculations for the analysis of protein computations in LCB samples. For each module that has been accessed by the user, the results of the composition analyzed are displayed in the analysis results display as shown in Figure 9.

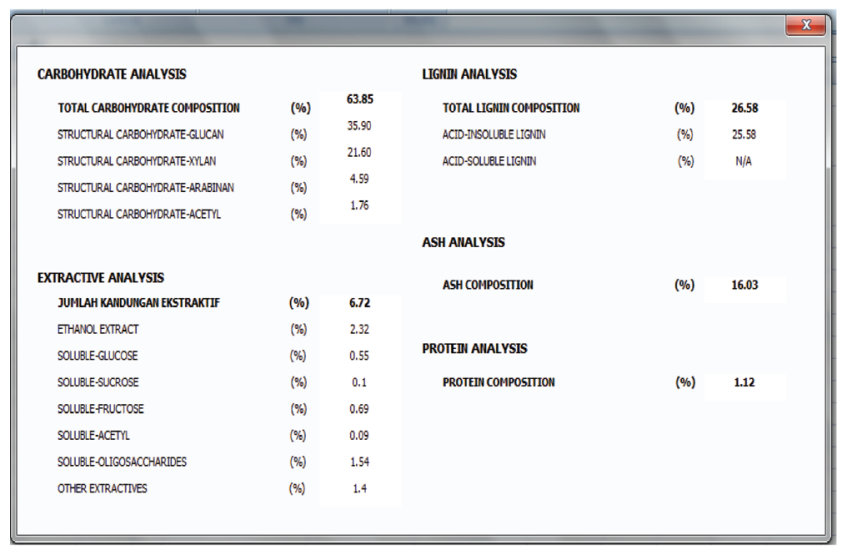

FIGURE 9. Result Display

To determine whether this developed software can be used, comparisons of the system and manual calculation is done to obtained percentage error for these two calculations.

The percentage error of the difference in the results of the systematic calculations and the use of the software is as shown in Table 1. This percentage of error is calculated by taking the ratio of difference in values in computational using system and manually calculation. Based on this calculation error, the percentage error for all major components such as carbohydrates, lignin, extractives, ash and proteins is less than 2 percent. This 2 percent error rate is an acceptable difference in the development of software, although in general software authentication, error less than 10 percent is allowed (John 2013).

For overall calculations, the results obtained from manual calculations and system calculations with their respective errors are concluded as in Table 1. Based on the result, the composition of rice straw calculated in this study consist of $62.06 \%$ structural carbohydrate, $26.24 \%$ klason lignin, $1.75 \%$ of acetyl group. Non-structural components consist of ash and extractive contain $6.03 \%$ and $6.72 \%$ respectively. Composition of same sample of rice straw reported by Harun et al. consist of $61.6 \%$ structural carbohydrate, $26.2 \%$ Klason lignin, $1.11 \%$ acetyl group and $16.8 \%$ of non structural extractive and ash. The compositions were as well compared with other compositional analysis result (Harun et al. 2013).

\section{CONCLUSION}

This paper has presented software to aid for LCB compositional analysis calculation. The software architecture has been developed in order to design the software. This software consist of overall calculation of biomass compositional analysis and as well as calculation by components. Thus this software includes five main modules which are ash module, protein module, extractives module, carbohydrate module and lignin module. The comparisons made by manual 
TABLE 1. Overall Results for Manual and System Calculations

\begin{tabular}{lrrrr}
\hline Component & Manual Calculation & System Calculation & Errors \% & Harun et al. 2013 \\
\hline Carbohydrate & $\mathbf{6 2 . 0 6}$ & $\mathbf{6 3 . 2 8}$ & $\mathbf{0 . 1 2 0}$ & $\mathbf{5 7 . 8}$ \\
Glucan & 34.87 & 35.90 & 0.030 & 34.4 \\
Xylan & 20.98 & 21.60 & 0.030 & 19.7 \\
Arabinan & 4.46 & 4.59 & 0.029 & 3.7 \\
Acetyl & 1.75 & 1.76 & 0.005 & 1.6 \\
Lignin & $\mathbf{2 6 . 2 4}$ & $\mathbf{2 6 . 5 8}$ & $\mathbf{0 . 0 1 3}$ & $\mathbf{1 9 . 8}$ \\
Acid soluble lignin & 26.24 & 26.58 & 0.013 & - \\
Acid insoluble lignin & - & - & - & - \\
Extractive & 6.72 & 6.72 & 0 & 6.7 \\
Ethanol Extractive & 2.32 & 2.32 & 0 & - \\
Soluble Glucose & 0.54 & 0.55 & 1.852 & - \\
Soluble Sucrose & 0.10 & 0.1 & 0 & - \\
Soluble Fructose & 0.68 & 0.69 & 1.471 & - \\
Soluble Acetyl & 0.09 & 0.09 & 0 & - \\
Soluble Oligosaccharide & 1.56 & 1.54 & 1.282 & - \\
Other extractive & 1.40 & 1.4 & 0 & - \\
Ash & $\mathbf{6 . 0 3}$ & $\mathbf{6 . 0 3}$ & $\mathbf{0}$ & $\mathbf{1 4 . 1}$ \\
Protein & $\mathbf{1 . 1 2}$ & $\mathbf{1 . 1 2}$ & $\mathbf{0}$ & $\mathbf{0 . 5}$ \\
TOTAL & $\mathbf{1 0 2 . 1 7}$ & $\mathbf{1 0 3 . 7 3}$ & $\mathbf{1 . 5 2 6 9}$ & $\mathbf{9 8 . 9}$ \\
\hline
\end{tabular}

and software calculation, then the result shows that the calculations are acceptable since the error deviated are less than 2\% (Walkenbach 2013).

\section{ACKNOWLEDGEMENT}

This research is funded by the Geran Universiti Penyelidikan (Grant \#: GUP-2016-007) on project entitled "Enhanced Hydrolysability Performance of Anhydrous Ammonia Pretreated Empty Fruit Bunch and Sago Bark Through Multivariate Optimization For Efficient Bioconversion: Effect of Particle Size and Glucan Loading", and also funded by the Fundamental Research Grant Scheme (Grant \#: FRGS/1/2016/TK02/UKM/02/4) on project entitled "Role of Ammonia And Pretreatment Conditioning Processes on Inhibitor Production: Inhibitory Effect And Tolerance In Downstream Processes". The primary and co-authors would like to especially thank the academic staffs and support staffs of CESPRO and Biorefinery Laboratory as well as other lab members for the assistance and support given during this research study.

\section{REFERENCES}

Demirbas, A. 2009. Biofuels securing the planet's future energy needs. Energy Conversion and Management 50(9): 2239-2249.

Dowe, N. \& Mcmillan, J. 2008. SSF experimental protocols: lignocellulosic biomass hydrolysis and fermentation laboratory analytical. Technical Report NREL. U.S.: National Renewable Energy Laboratory.

Deutschmann, R. \& Dekker, R. F. H. 2012. From plant biomass to bio-based chemicals: Latest developments in xylan research. Biotechnology Advances 30: 16271640.

Hames, B. R. 2009. Biomass compositional analysis for energy applications. In Methods in Molecular Biology. New York: Humana Press.

Hames, B., Ruiz, R., Scarlata, C., Sluiter, A., Sluiter, J. \& Templeton, D. 2008. Preparation of samples for compositional analysis. Technical Report NREL. U.S.: National Renewable Energy Laboratory

Hames, B., Scarlata, C. \& Sluiter, A. 2008. Determination of protein content in biomass. Technical Report NREL.U.S.:National Renewable Energy Laboratory

Harun, S., Jahim, J. M., Takriff, M. S. \& Hassan, O. 2015. Chemical composition of native and ammonia fiber expansion pretreated rice straw-unextracted versus extractive-free material. Jurnal Teknologi 74(3): 51-56.

Harun, S., Balan, V., Takriff, M. S., Hassan, O., Jahim, J. \& Dale, B. E. 2013. Performance of AFEX ${ }^{\mathrm{TM}}$ pretreated rice straw as source of fermentable sugars: the influence of particle size. Biotechnology for Biofuels 6(1): 40.

Kubicek C. P. 2012. Fungi and Lignocellulosic Biomass New Jersey: John Wiley \& Sons..

National Renewable Energy Laboratory. 1998. Chemical Analysis and Testing Laboratory Analytical Procedures U.S.: National Renewable Energy Laboratory

Silvério, S. 2013. Sustainable degradation of lignocellulosic biomass - techniques and application, edited by Chandel, A. K. \& da Silva, S. S. U.K.: Intechopen.

Singh, M., Singh, J. \& Fen, N. Y. 2011. Merekabentuk sistem laci pintar untuk penjejakan dokumen dengan menggunakan indentifikasi frekuensi radio (RFID). Jurnal Kejuruteraan 23: 37-48. 
Sluiter, A, Hames, B., Ruiz, R., Scarlata, C., Sluiter, J., Templeton, D. \& Crocker, D. 2008. Determination of structural carbohydrates and lignin in biomass determination of structural carbohydrates and lignin in biomass. Laboratory Analytical Procedure 1617: 1-16.

Sluiter, A., Hames, B., Ruiz, R. O., Scarlata, C., Sluiter, J., \& Templeton, D. 2008. Determination of ash in biomass. Technical Report NREL. U.S.: National Renewable Energy Laboratory

Sluiter, A., Hames, B., Ruiz, R., Scarlata, C., Sluiter, J., Sluiter, J. \& Templeton, D. 2008. Determination of extractives in biomass. Laboratory Analytical Procedure (LAP). Technical Report NREL. U.S.: National Renewable Energy Laboratory.

Sluiter, J. B., Ruiz, R. O., Scarlata, C. J., Sluiter, D. A. \& Templeton D. W. 2010. Compositional analysis of lignocellulosic feedstocks. 1. review and description of methods. Journal of Agricultural and Food Chemistry 58(16): 9043-9053.

Sluiter, J. \& Sluiter, A. 2011. Summative Mass Closure Laboratory Analytical Procedure (LAP) Review and Integration. Technical Report NREL. U.S.: National Renewable Energy Laboratory.

Templeton, D. W., Wolfrum, E. J., Yen, J. H. \& Sharpless, K. E. 2015. Compositional analysis of biomass reference materials: results from an interlaboratory study. BioEnergy Research 9(1): 303-314.
Vassilev, S. V., Baxter, D., Andersen, L. K. \& Vassileva, C. G. 2010. An overview of the chemical composition of biomass. Fuel 89(5): 913-933.

Vassilev, S. V., Baxter, D., Andersen, L. K., Vassileva, C. G. \& Morgan, T. J. 2012. An overview of the organic and inorganic phase composition of biomass. Fuel 94: $1-33$.

Walkenbach, J. 2013. Excel Programming VBA for dummies. New Jersey: John Wiley \& Sons.

*Shuhaida Harun, Nor Shahirah Ishak

Chemical Engineering Programme,

Research Centre for Sustainable Process Technology (CESPRO),

Faculty of Engineering \& Built Environment,

Universiti Kebangsaan Malaysia,

43600 UKM Bangi, Malaysia.

*Corresponding author; email:

harun.shuhaida@ukm.edu.my

Received date: $18^{\text {th }}$ April 2018

Accepted date: $17^{\text {th }}$ July 2018

Online First date: 1st October 2018

Published date: $30^{\text {th }}$ November 2018 